\title{
Identification of Sarcoptes scabiei by Clinical Examination and Follow-up Examination in Medan City, Indonesia
}

\author{
Afrida Aryani Nasution ${ }^{1 *(D)}$, Imam Budi Putra ${ }^{2}$ (D) Mutiara Indah Sari ${ }^{3}$ \\ ${ }^{1}$ Master Program in Tropical Medicine, Faculty of Medicine, Universitas Sumatera Utara, Medan, Indonesia; ${ }^{2}$ Department \\ of Dermatology and Venereology, Faculty of Medicine, Universitas Sumatera Utara, Medan, Indonesia; ${ }^{3}$ Department of \\ Biochemistry, Faculty of Medicine, Universitas Sumatera Utara, Medan, Indonesia
}

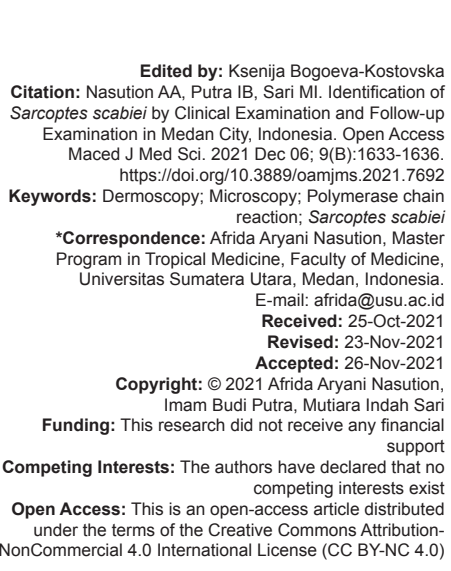

Introduction

Scabies is a disease caused by the mite Sarcoptes scabiei var. hominis. Scabies is acquired mainly under conditions of density and poor personal hygiene or during sexual contact [1]. The mites microscopically burrow into the skin and lay eggs, eventually triggering a host immune response that leads to intense itching and rash. Scabies infestation can be complicated by bacterial infection, leading to the development of skin sores which, in turn, can lead to more serious ones such as septicemia, heart disease, and chronic kidney disease [2].

Globally, scabies is estimated to affect more than 200 million people at any time. The prevalence in the recent scabies-related literature ranges from $0.2 \%$ to $71 \%$ [3]. A very high prevalence of scabies has been reported in India, the South Pacific, and Northern Australia. In a study of young people in rural India, the prevalence of scabies was $70 \%$, and Aboriginal Australians were reported to be $50 \%$. In Indonesia, scabies ranks third of the 12 most common skin diseases [4]. Previous studies have shown that the prevalence of scabies in Islamic boarding schools is quite high. In East Jakarta, the prevalence of scabies was $51.6 \%$, (57.4\% male and $42.9 \%$ female; tsanawiyah $0.1 \%$, and aliyah $41.3 \%$ ) with the most locations of scabies lesions on the buttocks $(33.8 \%)$ and between the fingers (29.2\%) [5]. In Jember, the prevalence of scabies was $13.48 \%$ (male $24.89 \%$ and female $5.82 \%$; tsanawiyah $15.14 \%$ and aliyah $10.85 \%$ ) with the most locations of scabies lesions between the fingers $(40.40 \%)$. The number of scabies sufferers at the Darul Arafah Islamic Boarding School who came for treatment to the clinic was 84 people throughout 2018 [6].

Visualization of dermatitis from mites in burrows has a limited role in diagnosis, with a sensitivity of $11 \%$, and microscopy of skin scrapings is even less sensitive. Nevertheless, this method is very specific and useful for confirming that the suspected outbreak is scabies [7], [8]. The sensitivity of the microscopic examination was $58.6 \%$ while the polymerase chain reaction (PCR) examination showed a sensitivity of $100 \%$. A study also conducted by Dupuy et al., 2007 showed the sensitivity of dermoscopy examination was $91 \%$ and microscopic examination was $90 \%$. Research 
on the sensitivity and specificity of dermoscopy in Medan found $66.67 \%$ and $61.29 \%$, respectively [9].

In cases of atypical scabies, a skin biopsy can help establish the diagnosis. Although not yet tested in controlled trials in large study populations, new diagnostic methods for scabies that are currently under investigation include enhanced microscopic techniques (e.g., chemiluminescence microscopy, digital dermoscopy, or video dermoscopy), immunological detection of scabies-specific antibodies by enzyme-linked immunosorbent assay, and molecular identification of scabies antibodies. scabies DNA by PCR assay [8]. In Indonesia, there is no data regarding the detection of scabies at the molecular and dermoscopy levels, so the authors are interested in researching scabies examination using PCR and dermoscopy methods in Medan.

\section{Methods}

This study is a cross-sectional study, descriptive-analytic to see the incidence of scabies with clinical symptoms and supporting examinations with PCR and dermoscopy examination methods. This research was conducted at the Molecular Laboratory of the USU Medical Faculty and the USU Medical Faculty Parasitology Laboratory. This research was carried out after obtaining approval from the USU Medical Research Ethics Commission. Sampling was carried out in various orphanages and boarding schools in the City. The research time is September 2019 - January 2021 with the sample subjects that meet the inclusion and exclusion criteria. The minimum number of samples used in this study with a simple random sampling formula with a sample of 50 people. Inclusion criteria in this study were students aged 13-17 years who were diagnosed with scabies and were willing to participate/include their children in the study by signing an informed consent (represented by parents or teachers). Exclusion criteria were students who were treated for scabies in the past week with topical scabies drugs, and students who had nodular scabies, bullous scabies, and incognito scabies.

This research was conducted by collecting subjects who met the inclusion and exclusion criteria. Then, the researchers conducted a dermoscopy and skin scrapping using mineral oil for microscopy examination after that the skin tissue were put in microtube $1.5 \mathrm{ml}$ with $180 \mu \mathrm{l}$ Buffer GA for DNA extraction. DNA was extracted from the skin scrapping by the following its DNA kit protocol, TIANamp micro DNA kit handbook by Tiangen. The dermoscopy examination if a delta wing sign/jet with contrail was found, it was interpreted as positive S. scabiei, and if no delta wing sign/jet with contrail was found, then $S$. scabiei was negative. For PCR examination, the sample it is interpreted that if a band at $135 \mathrm{bp}$ is found, it is positive for $S$. scabiei and if there is no band at $135 \mathrm{bp}$, it is negative for S. scabiei. The dermoscopy and PCR examination data that have been collected are described in tabular form. Results of PCR examination are shown in Figure 1 and 2.

\section{Protocol of PCR universal diagnosis}

The primer that we used was forward primer SSUDF 5'- GGG TCT TTT TGT CTT GGA ATA AA-3' and reverse primer SSUDR 5'- CTAAGG TAG CGAAAT CAT TAG C-3' with estimated size of $135 \mathrm{bp}$. The final protocol for the diagnosis of $S$. scabiei after adjusting the PCR mixture and the annealing temperature consisted of a total volume of $25 \mu \mathrm{L}$ PCR mixture composed of mastermix 2x Gotaq 12,5 $\mu \mathrm{L}, 10$ forward primer $1 \mu \mathrm{L}$, 10 reverse primer $1 \mu \mathrm{L}$, nuclease-free water $5,5 \mu \mathrm{L}$, and DNA S. scabiei $5 \mu \mathrm{L}$. The next step was thermal profile for amplification (Applied Biosystems, Foster City, California): $15 \mathrm{~min}$ at $95^{\circ} \mathrm{C}$ (initial denaturing), followed by $94^{\circ} \mathrm{C}$ (denaturation), $45 \mathrm{~s}$ at $48^{\circ} \mathrm{C}$ (annealing) and $1.5 \mathrm{~min}$ at $72^{\circ} \mathrm{C}$ (extension), before a final elongation of $7 \mathrm{~min}$ at $72^{\circ} \mathrm{C}$. The amplicons were examined on $2 \%$ agarose gel and stained with ethidium bromide for DNA visualization under ultraviolet light.

\section{Results}

This study was followed by 50 people from the Mamiyai Orphanage, Muhammadiyah Orphanage, and Darul Hikmah Islamic Boarding School who had met the inclusion criteria. Table 1 presents the demographic characteristics ofthe research subjects. Most of the students who were the subjects of this study were male, amounting to 40 people (80\%). The mean age of children participating in this study was 14.22 years (SD = 1529 years).

Table 1: Characteristics of research subjects

\begin{tabular}{ll}
\hline Demographic characteristics & $\mathrm{n}=50$ \\
\hline Gender, $\mathrm{n}(\%)$ & \\
Male & $40(80)$ \\
Female & $10(20)$ \\
Age, mean (SD), years & $14,22(1,53)$ \\
\hline
\end{tabular}

Table 2 shows the results of the identification of a typical scabies rash based on location, which showed on the head as many as 2 people (4\%), wrists as many as 7 people (14\%), between fingers 13 people (26\%), between toes 13 people (26 people). \%), groin as many as 2 people (4\%), buttocks 7 people (14\%), and external genitalia as many as 6 people (12\%).

Table 2: Identify the location of the scabies rash

\begin{tabular}{lll}
\hline Rash location & $\mathrm{n}=50$ & $\%$ \\
\hline Head & 2 & 4.0 \\
Wrists & 7 & 14.0 \\
Between hand & 13 & 26.0 \\
Between foot & 13 & 26.0 \\
Groin & 2 & 4.0 \\
Buttocks & 7 & 14.0 \\
External genitalia & 6 & 12.0 \\
\hline
\end{tabular}

Table 3 shows that the results of microscopic examination as the gold standard did not reveal any scabies $(0.0 \%)$, with other supporting examinations, 
Table 3: Results of scabies examinations

\begin{tabular}{lll}
\hline Examinations & $\mathrm{n}=50$ & $\%$ \\
\hline Microscopic & & \\
$\quad$ Found & 0 & 0,0 \\
$\quad$ Not found & 50 & 100 \\
Dermoscopic & & \\
$\quad$ Found & 0 & 0,0 \\
$\quad$ Not found & 50 & 100 \\
PCR & 12 & 24 \\
$\quad$ Found & 38 & 76 \\
$\quad$ Not found & &
\end{tabular}

namely, dermoscopy, no scabies $(0.0 \%)$, and PCR found 12 positive samples of scabies $(24 \%)$.

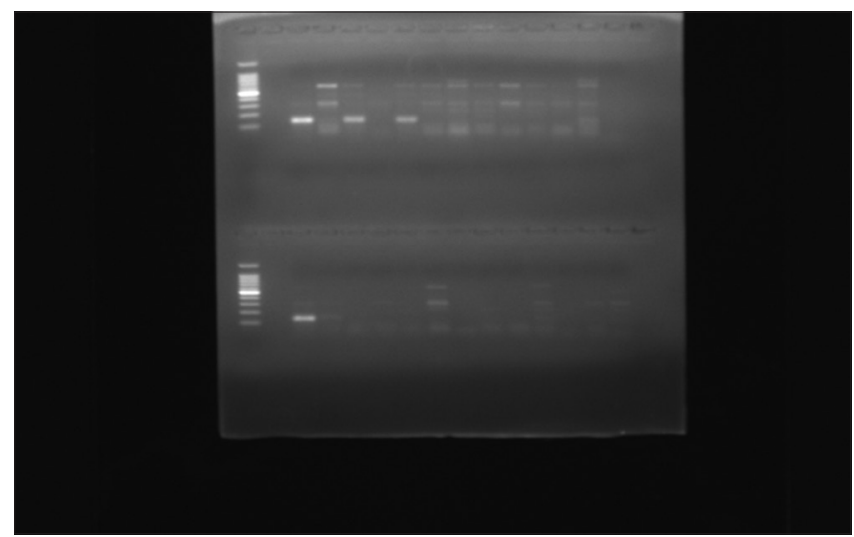

Figure 1: Sarcoptes scabiei DNA samples with sample numbers 1-12 (top) and 39-50 (bottom)

\section{Discussion}

Scabies is a disease associated with overcrowding and hygiene behavior. The study was conducted at the Mamiyai Orphanage, Muhammadiyah Orphanage, and Darul Hikmah Islamic Boarding School in 2021. The results showed that from 50 people who met the inclusion criteria, three of the four cardinal signs of scabies were found. In 50 samples that met the inclusion criteria, no $S$. scabiei bacteria were found through microscopic and dermoscopic examination, while the PCR examination found 12 positive samples

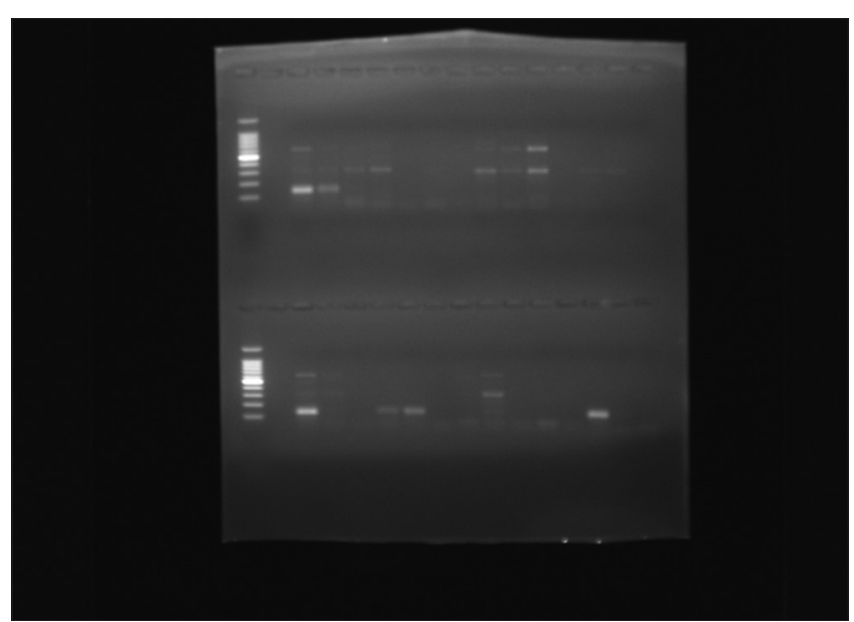

Figure 2: Sarcoptes scabiei DNA samples with sample numbers 13-39 of scabies [6], [10]. The PCR examination was declared positive if there was a DNA band at $135 \mathrm{bp}$ [9]. The positive samples are sample numbers $2,4,11,13,28$, 29, 32, 36, 39, 47, 49, and 50.

The population in this study was 245 people, 12 of whom were infected with scabies through PCR examination. The incidence rate in this study is $4.9 \%$, which is below the prevalence rate carried out by Kurniati et al., which is $12.3 \%$, and the prevalence in Grobogan Islamic Boarding School is $28.7 \%$. The area of predilection for scabies lesions in one individual can include several places, in this study the highest predilection was between the fingers and toes of $26 \%$ each, this is also by research conducted by Kurniati et al., of $21 \%$. The results of the dermoscopy examination in this study did not find the presence of S. scabiei or its eggs, this is different from the research conducted by Kurniati et al. found that $S$. scabiei through dermoscopy examination was $56.8 \%$. A similar study was also conducted by Nasution et al., (2014) where 14 people $(66.67 \%)$ were diagnosed with scabies using dermoscopy from a total of 34 samples [10].

In this study, it showed that samples were detected from PCR examination, namely $12(24 \%)$ of 50 samples detected S. scabiei DNA, this is following research conducted by Wong et al., that the PCR tool has a high sensitivity of $100 \%$ [8]. PCR examination in diagnosing scabies used two types of primers for $S$. scabiei which were at $170 \mathrm{bp}$ and $600 \mathrm{bp}$, respectively, the difference in basepair was probably due to heteroplasmy in the mite population [11]. In this study, a primer with an estimate of $135 \mathrm{bp}$ was used with a forward primer SSUDF and a reverse primer, namely SSUDR, which was under the research conducted by Alasaad et al. There is a difference in temperature in the annealing process carried out by researchers and Alasaad et al., namely the annealing temperature in this study was $48^{\circ} \mathrm{C}$ while in that study it was at a temperature of $53^{\circ} \mathrm{C}$ [12].

\section{Strength and Limitation}

Further research is needed to assess the sensitivity and specificity of dermoscopy and PCR in diagnosing scabies. It is necessary to conduct training or practicum for medical students in taking skin scraping specimens on scabies because the mites are easy to move and difficult to get. It is also necessary to conduct training or workshops for final year students or general practitioners in the use of dermoscopy as a non-invasive diagnostic tool for infectious skin diseases in general and scabies in particular.

\section{Conclusion}

This study is a descriptive study with a sample of 50 . The results found that based on gender there were $80 \%$ 
male and $20 \%$ female with an average age of 14 years. Based on the location of the rash, the most rashes were between the fingers and toes, each $26 \%$ and the least on the head as much as $2 \%$. Supportive examinations carried out included microscopic, dermoscopy, and PCR. On microscopic examination, which is the gold standard in diagnosing scabies, no mites or lice were found in skin scrapings, as well as dermoscopy. In PCR examination, DNA bands were found in 12 samples (24\%). This shows that the PCR assay is very sensitive and specific even in very small quantities.

The diagnosis of scabies is limited by the lack of accurate and objective tests. Microscopy of skin scrapings can confirm the diagnosis but is insensitive, invasive, and often impractical. Diagnosis usually relies on clinical judgment, although visualization using dermoscopy is becoming increasingly common [13]. These diagnostic methods are not standardized, hindering the interpretation of findings from clinical studies and epidemiological surveys, and the development of scabies control strategies.

\section{References}

1. Patterson JW. Arthropod-induced disease. In: Weedon's Skin Pathology. $4^{\text {th }}$ ed. United States: Elsevier; 2016. p. 767-80.

2. World Health Organization. Neglected Tropical Disease. Geneva: World Health Organization; 2015.

3. Hay RJ, Steer AC, Engelman D, Walton S. Scabies in the developing world-its prevalence, complications, and management. Clin Microbiol Infect. 2012;18(4):313-23. https:// doi.org/10.1111/j.1469-0691.2012.03798.x

PMid:22429456

4. Mading M, Sopi IP. Kajian aspek epidemiologi skabies pada manusia. J Penyakit Bersumber Binatang. 2015;2(2):9-18. https://doi.org/10.22435/jpbb.v1i2.4032.1-14
5. Ratnasari AF, Sungkar S. Prevalensi skabies dan faktorfaktor yang berhubungan di pesantren $\mathrm{x}$ jakarta timur. J UI. 2014;2(1):3177. https://doi.org/10.23886/ejki.2.3177

6. Sutejo IR, Rosyidi VA, ZaelanyAI. Prevalensi, karakteristik dan faktorfaktor yang berhubungan dengan penyakit skabies di pesantren nurul qarnain kabupaten jember (the prevalence, characteristic and factors of scabies in pesantren nurul qarnain jember). J Pustaka Kesehatan. 2017;5(1):30-4. https://doi.org/10.25047/jii.v16i2.299

7. Engelman D, Steer AC. Diagnosis, treatment, and control of scabies: Can we do better? Lancet Infect Dis. 2018;18(8):8223. https://doi.org/10.1016/s1473-3099(18)30372-4 PMid:30068496

8. Wong SS, Poon RW, Chau S, Wong SC, To KK, Cheng VC, et al. Development of conventional and real-time quantitative PCR assays for diagnosis and monitoring of scabies. J Clin Microbiol. 2015;53(7):2095-102. https://doi.org/10.1128/ jcm.00073-15 PMid:25903566

9. Dupuy A, Dehen L, Bourrat E, Lacroix C, Benderdouche $M$, Dubertret L, et al. Accuracy of standard dermoscopy for diagnosing scabies. J Am Acad Dermatol. 2007;56(1):53-62. https://doi.org/10.1016/j.jaad.2006.07.025 PMid:17190621

10. Kurniati K, Zulkarnain I, Listiawan MY. Kesesuaian gambaran klinis patognomonis infestasi skabies dengan kepositifan pemeriksaan dermoskop dan kerokan kulit (the concordance of clinical pathognomonic manifestation of scabies with positivity of dermoscop and skin scraping). Berkala IImu Kesehatan Kulit Kelamin. 2014;26(1):14-21. https://doi.org/10.20473/bikk.v33.2.2021.141-144

11. Walter B, Heukelbach J, Fengler G, Worth C, Hengge U, Feldmeier $\mathrm{H}$. Comparison of dermoscopy, skin scraping, and the adhesive tape test for the diagnosis of scabies in a resourcepoor setting. Arch Dermatol. 2011;147(4):468-73. https://doi. org/10.1001/archdermatol.2011.51

PMid:21482897

12. Alasaad SA, Min AM, Paquetti M, Alagaili AN, Amelio S, Berilli F, et al. Universal conventional and real-time PCR diagnosis tools for Sarcoptes scabiei. Parasites Vectors. 2015;8(1):1-7. https:// doi.org/10.1186/s13071-015-1238-y PMid:26568063

13. Marghoob AA, Usatine RP. Dermoscopy. In: Dermatologic and Cosmetic Procedures in Office Practice. Philadelphia, PA: Elsevier; 2012. p. 384-403. 